\title{
Semptomatik düzelme ve NTproBNP düşüşü olmayan olgularda sakubitril/valsartan'ın klinik yarar sağlamadığı düşünülebilir mi?
}

\author{
Dr. Nihan Kahya Eren
}

İzmir Katip Çelebi Üniversitesi, Atatürk Eğitim ve Araştırma Hastanesi, Kardiyoloji Kliniği, İzmir

Sakubitril/valsartan düşük ejeksiyon fraksiyonlu kalp yetersizliği (DEF-KY) tedavisinde klavuzlara yeni giren ve PARADIGM-HF çalışmasında enalapril ile karşılaştırıldığgnda kardiyovasküler (KV) mortalite veya KY hospitalizasyonu \%20 ( $<<0.001), \mathrm{KV}$ mortaliteyi \%20 $(\mathrm{p}<0.001)$, KY nedenli hastaneye yatışları \%21 $(\mathrm{p}<0.001)$ ve tüm nedenlere bağlı mortaliteyi \%16 azalttığ 1 kanıtlanmış bir ajandır. ${ }^{[1,2]}$ Sakubitril/valsartanın mortalite ve morbidite faydaları yanında, DEF-KY hastalarında semptomları ve yaşam kalitesini düzelttiği, sol ventrikül fonksiyonu üzerinde olumlu etkilerinin olduğu ve natriüretik peptid düzeylerinde anlamlı azalma sağladığı gösterilmiştir. ${ }^{[3-5]}$

Natriüretik peptidler KY'de önemli bir prognoz göstergesi olup, yüksek natriüretik peptid düzeyleri mortalite ve klinik olaylar ile ilişkilidir. ${ }^{[6,7]} \mathrm{KY}$ ilerledikçe, NYHA sınıfı kötüleştikçe natriüretik peptid düzeyleri de artmaktadır. Diğer taraftan mortalite ve morbidite faydaları kanıtlanmış tedavilerin uygun dozlarda kullanılmasını takiben, bu tedavilerin prognoz üzerine olumlu etkilerine paralel olarak natriüretik peptid düzeylerinde de azalma saptanmaktadır. Ancak KY'si ilerlemiş, yüksek riskli olgularda, kanıta dayalı farmakolojik tedaviye rağmen natriüretik peptid düzeyleri yüksek sebat edebilmektedir. ${ }^{[6,8]}$ Yüksek riskli DEF-KY'si olan hastaların dahil edildiği GUIDE-IT çalışmasında, natriüretik peptid düzeyine göre optimize edilen farmakolojik tedaviye karş1lık; kliniğe göre optimize edilen farmakolojik tedavinin, klinik sonlanımlar üzerine etkileri araştırılmıştır. ${ }^{[9]} \mathrm{Bu}$ çalışmanın yapıldığ 1 döneme bağlı olarak çalışmaya alınan hastalarda sakubitril/valsartan kullanılmamıştır. Her iki tedavi stratejisinde de hastalar tedavi optimizasyonu ve doz titrasyonu açısından sık klinik vizitler ile yakın takip edilmelerine rağmen; hastaların ancak sirasıyla \%46 ve\%40'ında NT-ProBNP düzeyleri hedef değerin altına gerilemiştir. NT-ProBNP düzeyi hedef değer olan 1000 pg/ml'nin altına düşen hastalarda, NT-proBNP düzeyi hedef değerin üzerinde sebat eden hastalara göre, kardiyovasküler mortalite ve KY'e bağlı hastaneye yatışların daha az (HR: 0.26; \%95 CI: 0.15 to $0.46 ; \mathrm{p}<0.001)$ ve hayat kalitelerinin daha iyi olduğu saptanmıştır. ${ }^{[10]}$ Dolayısıyla DEF-KY hastalarında farmakolojik tedaviye natriüretik yanıtın olmaması kalp yetersizliğinin ileri evrelerine ve daha yüksek riskli hastalara işaret etmektedir.

DEF-KY hastalarında sakubitril/valsartan'nın enalaprile karşı üstünlüğünün gösterildiği PARADIGMHF çalışmasına alınan hastaların önemli bir kısmını hafif-orta düzeyde semptomları olan hastalar oluşturmaktadır. ${ }^{[2]}$ Dolayısıyla sakubitril/valsartan'ın yüksek riskli, ileri evre DEF-KY hastalardaki etkinliği ile ilgili elimizdeki veriler kısıtlıdır. PARADIGMHF çalışmasının bir alt grup analizinde, sakubitril/ valsartan'ın, enalaprile kıyasla, NT-ProBNP düzeyleri üzerine etkisi ve randomizasyon sonrası NT-ProBNP düzeylerinde saptanan değişikliğin prognoz ile ilişkisi değerlendirilmiştir. ${ }^{[4]}$ PARADIGM-HF çalışmasının bu alt grup analizinde, NT-ProBNP düzeyindeki azalma, uygulanan tedavi stratejisinden bağımsız olarak, kardiyovasküler mortalite ve KY nedenli hastaneye yatış riskinde azalma ile ilişkili bulunmuştur. Her iki tedavi stratejisinin NT-proBNP düzeylerine etkisine bakıldığında ise; sakubitril/valsartan alan hastalarda hem ortalama NT-ProBNP düzeyleri daha fazla düşmüş (938 [IQR: 511-1595] pg/ml'ye karş1lik 1203 [IQR: 711-2061] pg/ml; p<0.001); hem de NT-ProBNP düzeyinde azalma izlenen hasta oranı enalapril koluna göre anlamlı olarak daha yüksek saptanmıştır. Hastaların basal NT-ProBNP düzeyleri quartillere ayrılarak değerlendirildiğinde, sakubitril/ valsartan NT- ProBNP'nin her bir quartilinde enalaprile kıyasla primer sonlanım noktalarını azaltmada daha etkin saptanmıştır (Şekil 1). Dolayısıyla her ne kadar PARADIGM-HF çalışmasına dahil edilen hastaların önemli bir kısmını hafif-orta düzeyde semp- 


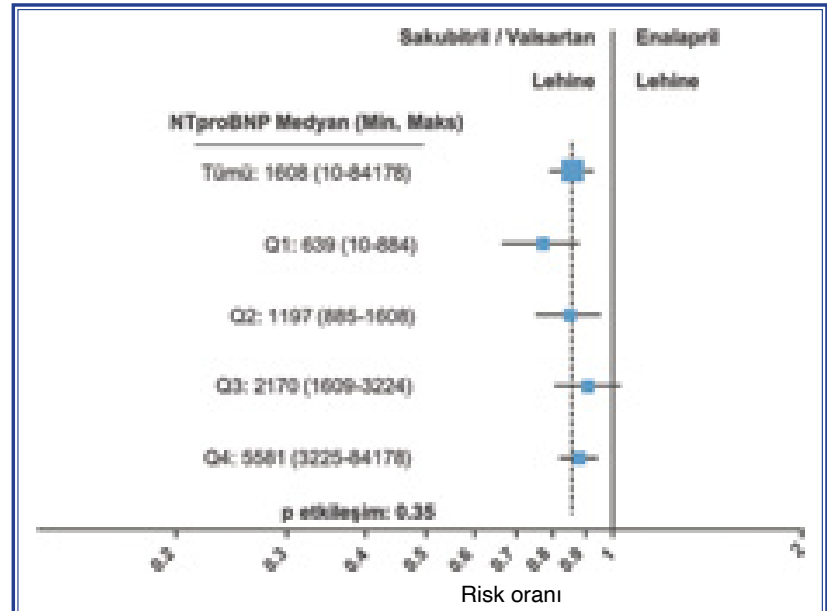

Şekil 1. Hastaların basal NT-ProBNP düzeyine göre sakubitril/valsartan ve enalaprilin birincil sonlanım noktalarına etkisi.

tomları olan hastalar oluştursa da; sakubitril/valsartan bu hasta grubunda basal NT-ProBNP düzeyine göre daha riskli olan hastalarda da KV olayları azaltmada enalaprile göre üstün bulunmuştur.

DEF-KY hastalarının yönetiminde mortalite ve morbidite faydaları kanıtlanmış ilaç tedavileri, tedavinin temelini oluşturmaktadır. Kanıta dayalı ilaç tedavilerinden beklenen faydanın en üst düzeyde sağlanabilmesi için bu tedavilerin tolere edilebilen maksimum dozlarda kullanılması önemlidir. Klinik pratikte, hastalarda ilaca bağlı hipotansiyon, hiperkalemi, kreatinin düzeylerinde yükselme veya semptomlarda kötüleşme olacağı endişesi ile kanıta dayalı tedavilerde doz up-titrasyonu yapılmamaktadır. Sakubitril/valsartan alan olgularda semptomatik düzelme ve NTproBNP düşüşü klinik yarar sağlandığını ortaya koyan önemli bulgulardır. Ancak sakubitril//valsartan almasına rağmen semptomatik düzelme ve NTproBNP düşüşü izlenmeyen olgularda mortalite ve morbidite yararının sağlanmayacağına ilişkin bir veri yoktur ve bu olgularda da öncellikle hastanın tolere ettiği maksimum dozlara çıkılması hedeflenmelidir.
Buna rağmen NT-ProBNP düşüşü izlenmeyen olgularda da, PARADIGM HF çalışmasının sonuçlarından elde edilen güçlü kanıtlar 1şığında, tolere edilen maksimum dozlarda tedaviye devam edilmesi en doğru yaklaşım olarak kabul edilmelidir.

\section{Kaynaklar}

1. Ponikowski P, Voors AA, Anker SD, Bueno H, Cleland JG, Coats AJ $\mathrm{SD}$, et al. 2016 ESC guidelines for the diagnosis and treatment of acute and chronic heart failure. Eur Heart J 2016;37:2129-200.

2. McMurray JJ, Packer M, Desai AS, Gong J, Lefkowitz MP, Rizkala $\mathrm{AR}$, et al. Angiotensin-neprilysin inhibition versus enalapril in heart failure. N Engl J Med 2014;371:993-1004.

3. Lewis EF, Claggett BL, McMurray JJV, Packer M, Lefkowitz MP, Rouleau JL, et al. Health-Related Quality of Life Outcomes in PARADIGM-HF. Circ Heart Fail 2017;10:e003430.

4. Zile MR, Claggett BL, Prescott MF, McMurray JJ, Packer M, Rouleau JL, et al. Prognostic Implications of Changes in N-Terminal ProB-Type Natriuretic Peptide in Patients With Heart Failure. J Am Coll Cardiol 2016;68:2425-36.

5. Januzzi JL Jr, Prescott MF, Butler J, Felker GM, Maisel AS, McCague $\mathrm{K}$, et al. Association of Change in N-Terminal Pro-B-Type Natriuretic Peptide Following Initiation of Sacubitril-Valsartan Treatment With Cardiac Structure and Function in Patients With Heart Failure With Reduced Ejection Fraction. JAMA 2019;322:1-11.

6. Ibrahim NE, Januzzi JL Jr. Established and Emerging Roles of Biomarkers in Heart Failure. Circ Res 2018;123:614-29.

7. Fonarow GC, Peacock WF, Phillips CO, Givertz MM, Lopatin M; ADHERE Scientific Advisory Committee and Investigators. Admission B-type natriuretic peptide levels and in-hospital mortality in acute decompensated heart failure. J Am Coll Cardiol 2007;49:1943-50.

8. Gaggin HK, Truong QA, Rehman SU, Mohammed AA, Bhardwaj A, Parks KA, et al. Characterization and prediction of natriuretic peptide "nonresponse" during heart failure management: results from the ProBNP Outpatient Tailored Chronic Heart Failure (PROTECT) and the NT-proBNP-Assisted Treatment to Lessen Serial Cardiac Readmissions and Death (BATTLESCARRED) study. Congest Heart Fail 2013;19:135-42.

9. Felker GM, Anstrom KJ, Adams KF, Ezekowitz JA, Fiuzat M, Houston-Miller N, et al. Effect of Natriuretic Peptide-Guided Therapy on Hospitalization or Cardiovascular Mortality in High-Risk Patients With Heart Failure and Reduced Ejection Fraction: A Randomized Clinical Trial. JAMA 2017;318:713-20.

10. Januzzi JL Jr, Ahmad T, Mulder H, Coles A, Anstrom KJ, Adams $\mathrm{KF}$, et al. Natriuretic Peptide Response and Outcomes in Chronic Heart Failure With Reduced Ejection Fraction. J Am Coll Cardiol 2019;74:1205-17. 